\title{
Uji Efektivitas Waktu Pemberian dan Konsentrasi PGPR (Plant Growth Promoting Rhizobacteria) Terhadap Produksi dan Mutu Benih Kacang Tanah (Arachis hypogaea L.)
}

\author{
Author(s): Nailul Marom*(1); Rizal ${ }^{(1)}$; Mochamat Bintoro ${ }^{(1)}$ \\ (1) Program Studi Teknik Produksi Benih, Jurusan Produksi Pertanian, Politeknik Negeri Jember \\ * Corresponding author: nailulm23@gmail.com
}

\begin{abstract}
ABSTRAK
Produksi dan mutu benih kacang tanah (Arachis hypogaea L.) dapat ditingkatkan dengan menggunakan PGPR (Plant Growth Promoting Rhizobacteria). Tujuan dari penelitian ini adalah untuk mengetahui produksi dan mutu benih kacang tanah dengan perbedaan saat pemberian dan perbedaan konsentrasi PGPR. Penelitian ini dilaksanakan pada bulan Agustus sampai November 2016 dengan Rancangan Acak Kelompok (RAK) dengan 2 faktor. Faktor pertama adalah waktu pemberian PGPR terdiri dari saat perendaman (W1), saat tanam (W2) dan saat fase vegetatif (W3). Faktor kedua adalah konsentrasi PGPR yang terdiri dari $0 \mathrm{ml} / \mathrm{L}(\mathrm{K} 0), 7,5 \mathrm{ml} / \mathrm{L}$ (K1), $10 \mathrm{ml} / \mathrm{L}$ (K2), dan 12,5 ml/L (K3). Parameter yang diamati adalah pertambahan tinggi tanaman, umur berbunga rata-rata, jumlah polong per rumpun tanaman, berat basah polong per rumpun tanaman, berat kering polong per rumpun tanaman, bobot 100 butir benih, produksi polong kering per hektar, daya berkecambah benih, Kecepatan tumbuh Benih, Dan keserempakan tumbuh benih. Hasil penelitian menunjukkan bahwa perlakuan terbaik adalah konsentrasi PGPR 12,5 $\mathrm{ml} / \mathrm{L}$ yang memberikan pengaruh nyata sampai sangat nyata pada parameter pertambahan tinggi tanaman pada fase vegetatif (15 HST sampai $30 \mathrm{HST}$ ), pertambahan tinggi tanaman pada stadium pembentukan polong (30 HST sampai 45 HST), umur berbunga rata-rata, berat basah polong per rumpun, berat kering polong per rumpun, bobot 100 butir benih, dan produksi polong kering per hektar.
\end{abstract}

\section{Kata Kunci:}

Kacang tanah;

Kualitas benih;

PGPR;

Waktu

pemberian;

\begin{abstract}
Keywords: $\quad$ Production and quality of peanut seed (Arachis hypogaea L.) can be increased by using PGPR (Plant Growth Promoting Rhizobacteria). This reseach to determine the Granting time; $\quad$ production and quality of peanut seeds with a differences of time granting and PGPR Peanuts; concentration. This research held from August to November 2016 and conducted by Randomized Block Design with 2 factors. The first factor was the time granting of PGPR PGPR; $\quad$ consisted of soaking time (W1), planting time (W2) and time vegetative phase (W3). The Seed quality; $\quad$ second factor was the concentration of PGPR consisted of $0 \mathrm{ml} / \mathrm{L}(\mathrm{K} 0), 7,5 \mathrm{ml} / \mathrm{L}(\mathrm{Kl})$, $10 \mathrm{ml} / \mathrm{L}(\mathrm{K} 2)$, and $12,5 \mathrm{ml} / \mathrm{L}(\mathrm{K} 3)$. Parameters observed were plant height increment, average of flowering age, number of pods per clumps plant, fresh weight of pods per clumps plant, dry weight of pods per clumps plant, weighing 100 grains of seed, production of dry pods per hectare, testing of seed germination, rate of seed growing, and simultaneity of seed growing. The result showed that the best treatment was concentration of PGPR $12.5 \mathrm{ml} / \mathrm{L}$ which gave significant effect on parameters of increasing of plant height at the vegetative phase (15 DAP - 30 DAP), increasing of plant height at the formation of pods stadium (30 DAP - 45 DAP), average of flowering age, fresh weight of pods per plant, dry weight of pods per plant, weighing 100 grains of seed, and production of dry pods per hectare.
\end{abstract}




\section{PENDAHULUAN}

Indonesia adalah negara agraris yang sebagaian besar penduduknya memiliki mata pencaharian sebagai petani. Namun, jumlah impor pangan (beras) di Indonesia sangat besar yang mengindikasikan bahwa Indonesia belum mencapai kondisi tahan pangan. Ketahanan pangan dapat dicapai dengan diversifikasi pangan sehingga impor beras dapat dikurangi.

Bahan pangan pokok pengganti beras yang dapat digunakan adalah kacang tanah (Arachis hypogaea L.) karena termasuk tanaman polong - polongan atau legum bersuku Fabaceace dan merupakan kacang kedua terpenting setelah kedelai di Indonesia.

Pertumbuhan jumlah penduduk Indonesia mendorong meningkatnya kebutuhan konsumsi pangan termasuk kacang tanah sehingga akan meningkatkan kebutuhan benih tanaman pangan termasuk benih kacang tanah.

Namun produksi, produktivitas, dan luas panen kacang tanah mengalami penurunan tiap tahun di Indonesia. Menurut Badan Pusat Statistik (2015), pada tahun 2012 hingga 2015 mengalami penurunan produksi terus - menerus yaitu $1,568 \%, 8,948 \%$, dan $5,286 \%$. Penurunan ini terjadi karena lahan pertanian di Indonesia berkurang setiap tahun, sehingga perlu dilakukan program intensifikasi pada lahan pertanian.

\section{Plant Growth Promoting}

Rhizobacteria (PGPR) dapat dipakai dalam program intensifikasi pertanian karena merupakan bakteri di sekitar perakaran dan hidup berkoloni menyelimuti akar yang berfungsi untuk meningkatkan pertumbuhan tanaman yaitu sebagai merangsang pertumbuhan (biostimulants) dengan mensintesis dan mengatur konsentrasi berbagai zat pengatur tumbuh seperti giberellin, asam indol asetat, etilen, dan sitokinin, sebagai penyedia hara dengan mengikat $\mathrm{N} 2$ di udara secara asimbiosis dan melarutkan hara $\mathrm{P}$ dalam tanah, dan sebagai pengendali patogen tanah (bioprotectants) dengan cara menghasilkan berbagai metabolit anti patogen seperti siderophore, kitinase, $\beta$ 1,3- glukanase, sianida, dan antibiotic (Husen, et al., 2006) .

Penelitian yang telah dilakukan sebelumnya A'yun et al., (2013), aplikasi PGPR dengan konsentrasi $10 \mathrm{ml} / \mathrm{L}$ pada tanaman cabai rawit dapat menurunkan intensitas serangan TMV (Tobacco Mosaic Virus) sampai 89,92\%, meningkatkan produksi tanaman cabai, dan dapat meningkatkan tinggi tanaman cabai rawit. Penelitian Iswati, (2012) menunjukkan aplikasi PGPR dengan konsentrasi 12,5 $\mathrm{ml} / \mathrm{L}$ berpengaruh nyata terhadap tinggi tanaman dan panjang akar tanaman tomat, serta konsentrasi $7,5 \mathrm{ml} / \mathrm{L}$ dapat memaksimalkan jumlah daun dan jumlah akar pada tanaman tomat.

Aplikasi PGPR pada penyiapan benih buncis perancis memiliki nilai tertinggi pada parameter jumlah polong per tanaman, bobot per polong, bobot polong segar per tanaman, dan hasil panen. Aplikasi PGPR satu minggu setelah tanam memilki panjang polong yang lebih baik pada tanaman buncis perancis dan Aplikasi PGPR pada fase vegetatif yang diberikan satu minggu sekali pada fase vegetatif menunjukkan pertumbuhan buncis perancis yang lebih baik (Aiman et al., 2015).

Penggunaan PGPR dengan konsentrasi dan waktu pemberian dari pengguna sebelumnya tidak dapat diterapkan begitu saja tanpa memperhatikan kondisi lingkungan setempat sebagai tempat dimana PGPR diberikan sehingga perlu dilakuakan penelitian untuk memperoleh konsentrasi dan saat pemberian yang tepat agar tujuan yang ingin dicapai dapat terwujud.

Tujuan dari Penelitian ini adalah untuk mengetahui saat pemberian dan konsentrasi PGPR yang tepat untuk 
meningkatkan produksi dan mutu benih kacang tanah.

\section{BAHAN DAN METODE}

Penelitian Uji Efektivitas Kombinasi Saat Pemberian dan Konsentrasi PGPR Terhadap Produksi dan Mutu Benih Kacang Tanah (Arachis hypogaea L.) dilaksanakan pada bulan Agustus November 2016 di lahan Teknologi Benih Politeknik Negeri Jember dan Dusun Sumberbulus 2, Desa Sumberbulus, Kecamatan Ledokombo, Jember.

Alat yang digunakan pada penelitian ini adalah alat budidaya, bak perkecambahan dan alat pengukuran. Bahan yang digunakan adalah benih kacang tanah kelas Stock Seed (Varietas Tuban), PGPR (Plant Growth Promoting Rhizobacteria), pupuk Nitrogen (Urea), pupuk Phospor (SP-36), pupuk Kalium $(\mathrm{KCl})$, pestisida (fungisida dan insektisida) dan pasir.

Penelitian ini memakai Rancangan Acak Kelompok (RAK) Faktorial yang terdiri dari dua faktor. Faktor pertama yaitu waktu pemberian PGPR: W1 = Saat perendaman benih; W2 = Saat tanam; W3 $=$ Saat fase vegetatif mulai 7 HST. Faktor kedua yaitu konsentrasi PGPR, terdiri dari $\mathrm{K} 0=0 \mathrm{ml} / \mathrm{L}$ (Kontrol); $\mathrm{K} 1=7,5 \mathrm{ml} / \mathrm{L} ; \mathrm{K} 2$ $=10 \mathrm{ml} / \mathrm{L} ; \mathrm{K} 3=12,5 \mathrm{ml} / \mathrm{L}$. Keseluruhan sebanyak 12 kombinasi perlakkuan dan setiap kombinasi perlakuan diulang sebanyak 4 kali. Jika dari hasil sidik ragam menunjukkan bahwa yang memberikan pengaruh yang berbeda nyata adalah pada perlakuan maka uji lanjut yang digunakan adalah Beda Nyata Terkecil (BNT).

Persiapan lahan dilakukan dengan cara mengolah lahan dengan menggunakan traktor sebanyak 2 kali kemudian dibentuk bedengan dengan ukuran $100 \mathrm{~cm} \times 100 \mathrm{~cm}$ dan tinggi $30 \mathrm{~cm}$ sebanyak 12 bedengan.

Penyiapan benih untuk perlakuan PGPR yaitu dengan cara merendam benih sebanyak 72 biji untuk setiap perlakuan kedalam larutan PGPR. Penanaman dan perlakuan PGPR pada saat tanam dilakukan dengan cara menanam benih sebanyak 4 benih/lubang dengan jarak tanam $40 \mathrm{~cm} \times 25 \mathrm{~cm}$ sebanyak 6 lubang tanam, kemudian dikocor dengan larutan PGPR dengan dosis sesuai perlakuan.

Perlakuan PGPR Saat Fase Vegetatif dilakuan 1 minggu setelah tanam dan diulang 4 kali dengan dosis 250 $\mathrm{ml} /$ tanaman. Pemupukan susulan pertama dilakukan pada umur 7 hari setelah tanam (HST) dengan dosis pupuk Urea $25 \mathrm{~kg} / \mathrm{ha}$, SP-36 $100 \mathrm{~kg} / \mathrm{ha}$, dan $\mathrm{KCl} 100 \mathrm{~kg} / \mathrm{ha}$. Penyiraman dilakukan menyesuaikan dengan kondisi tanah dan kebutuhan tanaman. Penyiangan dan pembumbunan dilaksanakan saat tanaman berumur 2-3 dan 6-7 minggu setelah tanaman (saat berbunga). Pupuk susulan kedua diberikan pada umur 21 HST (Urea $25 \mathrm{~kg} / \mathrm{ha}$ ). Pengendalian hama dan penyakit dilakukan secara mekanis dan kimiawi (melihat tingkat keparahan serangan).

Panen dilakukan pada umur 85-110 HST (tergantung varietas) atau daun sebagian besar berwarna kuning dan gugur (rontok) dengan mencabut tanamam. Penanganan pasca panen dilakukan dengan membersihakn polong, kemudian dipipil, dan dijemur dibawah sinar matahari sampai kadar air 9-12\% atau selama 6 hari.

Parameter yang diamati meliputi pertambahan tinggi tanaman yang diukur mulai pangkal batang sampai titik tumbuh. Pertambahan tinggi tanaman fase vegetatif diperoleh dengan mengurangi tinngi tanaman umur 30 HST dengan umur 15 HST, pertambahan tinggi tanaman stadium pembentukan polong diperoleh dengan mengurangi tinggi tanaman umur 45 HST dengan umur $30 \mathrm{HST}$, dan pertambahan tinggi tanaman stadium pengisian polong diperoleh dengan mengurangi tinggi tanaman umur 60 HST dengan umur 45 HST.

Umur berbunga rata-rata dilakukan dengan mengamati tanaman sampel yang berbunga sampai tanaman sampel yang 
terakhir berbunga, kemudian diambil ratarata. Jumlah polong per tanaman dilakukan dengan cara menghitung polong berisi maupun polong hampa pada setiap tanaman sampel.

Berat basah polong per tanaman dilakukan dengan cara menimbang polong yang baru dipanen atau belum dilakukan penjemuran dengan menggunakan timbangan pada setiap tanaman sampel. Berat kering polong per tanaman dilakukan dengan cara menimbang polong yang telah kering dengan menggunakan timbangan pada setiap tanaman sampel. Berat 100 butir benih dilakukan dengan cara menimbang benih kering sebanyak 100 butir dan diulang 3 kali kemudian diambil rata-ratanya.

Mengkonversikan populasi yang terdapat dalam satu petak sesuai dengan jarak tanam ke dalam satuan hektar.

Pengujian daya berkecambah benih menggunakan metode dalam pasir dengan menjumlah persentase kecambah normal pada hari ke-5 (first count) dan hari ke-10 (final count). Kecepatan tumbuh benih dihitung dengan menjumlah persentase kecambah normal pada hari ke-1 sampai hari ke-10. Keserempakan tumbuh dihitung dengan cara menghitung kecambah normal kuat pada hari antara first count dan final count yaitu hari ke-8.

\section{HASIL DAN PEMBAHASAN \\ Pertambahan Tinggi Tanaman}

Pertambahan tinggi tanaman pada umur 15 HST sampai 30 HST dengan pemberian konsentrasi PGPR 12,5 ml/L (K3) mampu menghasilkan tinggi tanaman tertinggi yakni $15,46 \mathrm{~cm}$ walaupun tidak berbeda nyata dengan perlakuan PGPR konsentrasi $10 \mathrm{ml} / \mathrm{L}$ (K2) dan 7,5ml/L (K1). Pertambahan tinggi tanaman pada umur 30 HST sampai 45 HST dengan pemberian PGPR berbeda sangat nyata dengan pertambahan tinggi tanaman kacang tanah tanpa pemberian PGPR. \begin{tabular}{llcr}
\multicolumn{2}{c}{ Pemberian } & PGPR & dengan \\
konsentrasi & 12,5 & $\mathrm{ml} / \mathrm{L}$ & mampu \\
meningkatkan & tinggi & tanaman & karena
\end{tabular} PGPR dapat mengoptimalkan penyerapan dan pemanfaatan unsur hara $\mathrm{N}$ yang dibutuhkan dalam fase vegetatif. Lindung, (2014) menyatakan bahwa fungsi PGPR yaitu meningkatkan penyerapan dan pemanfaatan unsur hara $\mathrm{N}$ oleh tanaman. Unsur hara $\mathrm{N}$ berguna untuk menambah tinggi tanaman dan memacu pertunasan (Jumin, 2002). Hasil ini sesuai dengan penelitian Iswati (2012), bahwa tinggi tanaman tomat tertinggi dijumpai pada perlakuan pemberian PGPR 12,5 $\mathrm{ml} / \mathrm{L}$. Iswati, (2012), menyatakan semakin tinggi konsentrasi pemberian PGPR maka berbanding lurus dengan pertumbuhan tanaman.

Tabel 1. Perlakuan Konsentrasi PGPR Terhadap Rerata Pertambahan Tinggi Tanaman Berdasarkan Umur $(\mathrm{cm})$

\begin{tabular}{|c|c|c|}
\hline \multirow{4}{*}{ Perlakuan } & \multirow{2}{*}{\multicolumn{2}{|c|}{$\begin{array}{l}\text { Pertambahan } \\
\text { Tinggi Tanaman } \\
\text { Umur Ke- }\end{array}$}} \\
\hline & & \\
\hline & $15-30$ & $30-45$ \\
\hline & HST & HST \\
\hline Konsentrasi $0 \mathrm{ml} / 1$ & $12,46 \mathrm{a}$ & $13,49 \mathrm{a}$ \\
\hline Konsentrasi 7,5 ml/1 & $13,79 \mathrm{ab}$ & $15,32 \mathrm{~b}$ \\
\hline Konsentrasi $10 \mathrm{ml} / \mathrm{l}$ & $14,47 \mathrm{bc}$ & $16,11 \mathrm{~b}$ \\
\hline Konsentrasi $12,5 \mathrm{ml} / 1$ & $15,46 \mathrm{c}$ & $16,14 \mathrm{~b}$ \\
\hline Nilai BNT \% & 1,66 & 1,38 \\
\hline
\end{tabular}

Keterangan:

Angka-angka yang diikuti oleh huruf yang berbeda menunjukkan berbeda nyata.

Pertambahan tinggi tanaman pada umur 45 HST sampai 60 HST menunjukkan perlakuan yang diberikan memberikan pengaruh yang tidak nyata. Diduga ketersediaan unsur hara, $\mathrm{N}$ di dalam tanah telah mencukupi kebutuhan tanaman. selain itu, diduga pada umur 45 HST sampai 60 HST telah memasuki fase generatif. Pembentukan polong dimulai ketika ujung ginofor mulai membengkak, 
yaitu pada hari ke-40 sampai hari ke-45 setelah tanam.

\section{Rata-rata Umur Berbunga}

Rata-rata umur berbunga dengan pemberian PGPR berbeda sangat nyata dengan rata-rata umur berbunga tanpa pemberian PGPR (Tabel 2).

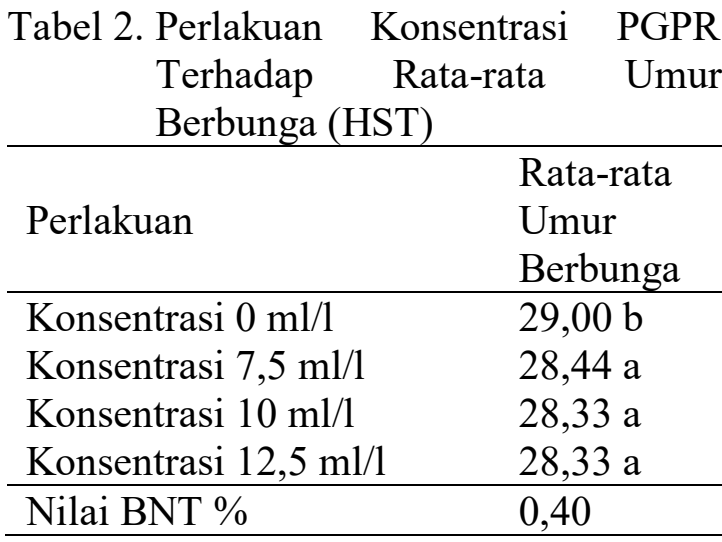

Keterangan :

Angka-angka yang diikuti oleh huruf yang berbeda menunjukkan berbeda nyata.

Diduga dengan pemberian PGPR dengan dapat mempercepat proses pembungaan karena bakteri Rhizobium akan membantu tanaman dalam penyerapan dan memenuhi kebutuhan unsur haranya. Lindung (2014) menyatakan bahwa bakteri PGPR berfungsi melarutkan dan meningkatkan ketersediaan unsur Phosphor (P) dan Mangan (Mn) dalam tanah serta meningkatkan kemampuan tanaman dalam menyerap unsur Sulfur (S). Hal ini didukung oleh pernyataan Aiman et al., (2015), menyatakan bahwa dengan tersedianya unsur hara fosfor maka akan mempercepat pembungaan. Fauziah Aini Rohmawati (2016) dalam penelitiannya menyatakan bahwa PGPR berpengaruh nyata terhadap umur berbunga, umur berbuah, umur panen pertama dan bobot buah per tanaman dengan perlakuan PGPR dibandingkan dengan perlakuan tanapa PGPR.

\section{Jumlah Polong per Rumpun}

Pemberian PGPR dengan perlakuan saat pemberian dan konsentrasi maupun interaksinya berpengaruh tidak nyata terhadap jumlah polong per rumpun. Hal ini diduga karena pengolahan tanah yang dilakukan dua kali sebelum tanam menyebabkan tanah menjadi gembur sehingga ginofor (kuncup buah) yang terbentuk setelah mencapai tanah akan mudah tumbuh dan berkembang membentuk polong. Tanah yang gembur akan memberikan keleluasaan bagi ginofor untuk berkembang secara optimal maka dari itu polong dapat terbentuk dengan mudah dan optimal. Hal ini sejalan dengan pernyataan Rukmana (1998) yang menyatakan bahwa kondisi tanah yang gembur akan memudahkan kuncup buah (ginofora) menembus tanah dan pembentukan polong yang baik.

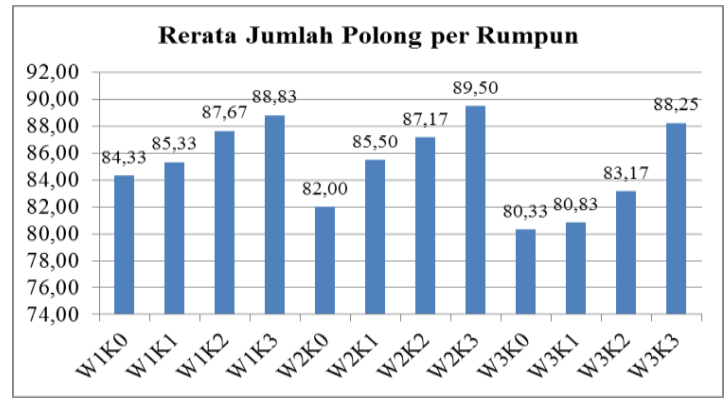

Gambar 1. Grafik Rerata Jumlah Polong per Rumpun (polong)

Jumlah polong per rumpun tertinggi cenderung pada perlakuan W2K3 yaitu sebesar 89,50 polong per rumpun (Gambar 1), walaupun secara stataistik hasil tersebut menunjukkan berbeda tidak nyata. Diduga pada pemberian PGPR saat tanam memberikan waktu bakteri untuk beradaptasi dengan lingkungan sehingga setelah umur tanaman mencapai 15 hari, bakteri PGPR mulai dapat membentuk bintil akar. Aplikasi PGPR pada tanah sesaat sebelum penanaman dengan konsentrasi 12,5 $\mathrm{ml} / \mathrm{L}$ memberikan pengaruh yang nyata terhadap 
pertumbuhan tanaman tomat (Iswati, 2012).

Jumlah polong tertinggi dengan perlakuan W2K3 juga berkaitan dengan rata-rata umur berbunga yang diperoleh dari perlakuan W2K3 yaitu berbunga pada 38,33 HST. Umur berbunga rata-rata yang cepat diduga akan mempercepat pembentukan polong, sehingga jumalah polong yang dihasilkan juga semakin tinggi. Hal ini sejalan dengan hasil penelitian Leingo (2014) yang menghasilkan data bahwa umur panen berkorelasi positif dengan jumlah buah tanaman tomat.

\section{Berat Basah Polong per Rumpun}

Perlakuan pemberian PGPR dengan konsentrasi 12,5 ml/L (K3) merupakan perlakuan terbaik dengan rata-rata 126,99 $\mathrm{g}$ walaupun berbeda tidak nyata dengan perlakuan PGPR konsentrasi $10 \mathrm{ml} / \mathrm{L}$ (K2), namun berbeda nyata dengan perlakuan PGPR konsentrasi 7,5 ml/L (K1) dan berbeda sangat nyata dengan perlakuan PGPR konsentrasi 0 ml/L (K0) (Tabel 3).

Tabel 3. Perlakuan Konsentrasi PGPR Terhadap Berat Basah Polong per Rumpun (g)

\begin{tabular}{ll}
\hline & $\begin{array}{l}\text { Berat } \\
\text { Basah } \\
\text { Polong per } \\
\text { Tanaman }\end{array}$ \\
& $116,55 \mathrm{a}$ \\
Konsentrasi $0 \mathrm{ml} / 1$ & $119,99 \mathrm{ab}$ \\
Konsentrasi $7,5 \mathrm{ml} / 1$ & $124,91 \mathrm{~b}$ \\
Konsentrasi $10 \mathrm{ml} / 1$ & $126,99 \mathrm{~b}$ \\
Konsentrasi $12,5 \mathrm{ml} / 1$ & 7,63 \\
\hline Nilai BNT \% & \\
\hline
\end{tabular}

Keterangan :

Angka yang diikuti oleh huruf yang berbeda menunjukkan berbeda nyata.

Hal ini diduga karena bakteri pada PGPR dapat melarutkan pupuk P sehingga penyerapan unsur hara $\mathrm{P}$ menjadi maksimal. Lindung, (2014) menyatakan bahwa fungsi pemberian PGPR adalah melarutkan dan meningkatkan ketersediaan unsur $\mathrm{P}$ dalam tanah. Unsur hara $\mathrm{P}$ bermanfaat untuk memperbaiki pembungaan pembentukan buah, dan pembentukan benih serta dapat mengurangi kerontokan buah (Jumin, 2002). Febriyanti et al. (2015) menyatakan bahwa penambahan PGPR menghasilkan bobot basah polong kacang tanah berbeda nyata dibandingkan perlakuan kontrol (tanpa PGPR).

\section{Berat Kering Polong per Rumpun}

Perlakuan pemberian PGPR dengan konsentrasi 12,5 ml/L (K3) merupakan perlakuan terbaik dengan rata-rata $82,27 \mathrm{~g}$ dan berbeda sangat nyata dengan perlakuan PGPR konsentrasi $10 \mathrm{ml} / \mathrm{L}$ (K2), 7,5 ml/L (K1), dan 0 ml/L (K0) (Tabel 4).

Tabel 4. Perlakuan Konsentrasi PGPR Terhadap Berat Kering Polong per Rumpun (g)

\begin{tabular}{ll}
\hline Perlakuan & $\begin{array}{l}\text { Berat Kering } \\
\text { Polong per } \\
\text { Rumpun }\end{array}$ \\
\hline Konsentrasi $0 \mathrm{ml} / 1$ & $72,65 \mathrm{a}$ \\
Konsentrasi $7,5 \mathrm{ml} / 1$ & $75,08 \mathrm{a}$ \\
Konsentrasi $10 \mathrm{ml} / 1$ & $79,40 \mathrm{~b}$ \\
Konsentrasi $12,5 \mathrm{ml} / 1$ & $82,27 \mathrm{c}$ \\
\hline Nilai BNT \% & 2,75 \\
\hline
\end{tabular}

Keterangan :

Angka yang diikuti oleh huruf yang berbeda menunjukkan berbeda nyata.

Diduga dengan pemberian PGPR konsentrasi $12,5 \mathrm{ml} / \mathrm{L}$ dapat membantu melarutkan dan meningkatkan ketersediaan unsur phosphor $(\mathrm{P})$ bagi tanaman untuk pembentukan organ generatifnya terutama pengisian biji. Dengan tercukupinya kebutuhan phospor (P) maka dapat meningkatkan hasil produksi biji kacang tanah. Hal ini sesuai dengan pernyataan Pitojo (2005) bahwa fosfor berperan dalam pembentukan biji.

Elfianti (2005) menyatakan bakteri pelarut fosfor (Bacillus sp) dalam tanah yang dipupuk fosfat dapat menambah jumlah dan bobot kering bintil akar serta 
hasil biji beberapa tanaman yang toleran masam (bayam, kacang panjang, dan jagung).

\section{Bobot 100 Butir Benih}

Bobot 100 butir benih dengan pemberian PGPR memberikan pengaruh berbeda sangat nyata dengan bobot 100 butir benih tanpa pemberian PGPR. Pemberian PGPR dengan konsentrasi 12,5 $\mathrm{ml} / \mathrm{L}$ diduga dapat meningkatkan bobot 100 butir benih karena bakteri dalam PGPR mampu melarutkan dan meningkatkan ketersediaan phospor (P) bagi tanaman, dan merangsang pembentukan hormon sehingga tanaman terlihat lebih subur. Anesta et al., (2016) dalam penelitiannya menyatakan bahwa penambahan PGPR mampu meningkatkan bobot 1000 butir gabah padi dibandingkan dengan kontrol.

Tabel 5. Perlakuan Konsentrasi PGPR Terhadap Bobot 100 Butir Benih (gr)

\begin{tabular}{ll}
\hline Perlakuan & $\begin{array}{l}\text { Bobot 100 } \\
\text { Butir } \\
\text { Benih }\end{array}$ \\
\hline Konsentrasi 0 ml/1 & $41,95 \mathrm{a}$ \\
Konsentrasi $7,5 \mathrm{ml} / 1$ & $42,90 \mathrm{~b}$ \\
Konsentrasi $10 \mathrm{ml} / 1$ & $43,47 \mathrm{~b}$ \\
Konsentrasi $12,5 \mathrm{ml} / 1$ & $44,31 \mathrm{~b}$ \\
\hline Nilai BNT \% & 1,61 \\
\hline $\begin{array}{l}\text { Keterangan : } \\
\text { Angka yang diikuti oleh huruf yang berbeda } \\
\text { menunjukkan berbeda nyata. }\end{array}$
\end{tabular}

\section{Produksi Polong Kering per Hektar}

Pemberian PGPR dengan perlakuan konsentrasi 12,5 ml/L (K3) merupakan perlakuan terbaik dengan rata-rata 4,94 ton per hektar dan berbeda sangat nyata dengan perlakuan PGPR konsentrasi $10 \mathrm{ml} / \mathrm{L}$ (K2), 7,5 ml/L (K1), dan $0 \mathrm{ml} / \mathrm{L}(\mathrm{K} 0)$.

Hal ini diduga pengaruh jumlah polong per rumpun dan berat kering polong per rumpun yang tinggi pada perlakuan yang sama yaitu K3 dengan hasil berturtturut 88,86 polong dan $82,27 \mathrm{~g}$, sehingga menghasilkan produksi polong kering per hektar pada perlakuan K3 juga tinggi.

Tabel 6. Perlakuan Konsentrasi PGPR Terhadap Produksi Polong Kering per Hektar (ton)

\begin{tabular}{ll}
\hline & $\begin{array}{l}\text { Produksi } \\
\text { Polong } \\
\text { Kering per } \\
\text { Hektar }\end{array}$ \\
& $4,36 \mathrm{a}$ \\
Konsentrasi $0 \mathrm{ml} / 1$ & $4,50 \mathrm{~b}$ \\
Konsentrasi $7,5 \mathrm{ml} / 1$ & $4,76 \mathrm{c}$ \\
Konsentrasi $10 \mathrm{ml} / 1$ & $4,94 \mathrm{~d}$ \\
Konsentrasi $12,5 \mathrm{ml} / 1$ & 0,04 \\
\hline Nilai BNT \% & . \\
\hline
\end{tabular}

Keterangan : Angka yang diikuti oleh huruf yang berbeda menunjukkan berbeda nyata.

Irfan (2013) dalam penelitiannya menyatakan bahwa aplikasi rizobakteri mampu meningkatkan bobot kering umbi bawang merah karena rizobakteri mampu menghasilkan IAA dan dapat berasosiasi dengan tanaman serta membantu proses dekomposisi bahan-bahan organik di dalam tanah sehingga penyerapan hara oleh tanaman lebih sempurna yang berpengaruh pada produktifitas tanaman.

\section{Daya Berkecambah Benih}

Perlakuan saat pemberian dan konsentrasi PGPR, maupun interaksinya berpengaruh tidak nyata terhadap daya berkecambah benih. Hal ini diduga karena benih yang dipakai dalam uji daya berkecambah berukuran besar pada setiap perlakuan. Ukuran benih yang besar sesuai dengan parameter bobot 100 butir benih yang menghasilkan bobot 100 butir benih berkisar antara 41,95 g sampai 44,31 g yang melebihi deskripsi bobot 100 butir benih kacang tanah Varietas Tuban yaitu berkisar anatara $35 \mathrm{~g}$ sampai $38 \mathrm{~g}$ (Suhartina, 2005).

Benih yang besar dapat menjadi kecambah normal karena memiliki cadangan makanan yang cukup. Sutopo (2002) menyatakan bahwa perkecambahan 
dipengaruhi oleh ukuran benih karena ukuran benih berpengaruh terhadap jaringan penyimpan cadangan makanan benih yang diperlukan embrio sebagai energi saat perkecamabahan.

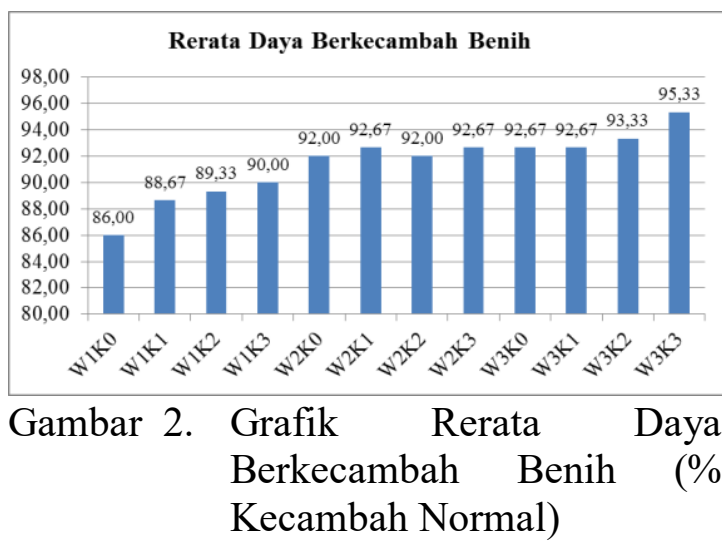

Gambar 2, memperlihatkan bahwa rerata daya berkecambah benih yang dihasilkan dari semua perlakuan tinggi. Benih yang menghasilkan kecambah normal lebih besar dari $85 \%$ dikelompokkan sebagai benih bervigor tinggi, $80-85 \%$ bervigor sedang, dan kurang dari $80 \%$ bervigor rendah.

Rerata daya berkecambah yang tinggi dan tidak berbeda nyata diduga dipengaruhi oleh ukuran benih yang besar pada semua perlakuan. Hal ini sesuai dengan parameter bobot 100 butir benih yang lebih tinggi dari deskripsi bobot 100 butir benih kacang tanah Varitas Tuban. Pratama et al., (2014) menyatakan bahwa benih berukuran besar mempunyai cadangan makanan yang lebih banyak sehingga pertumbuhan tanaman optimal.

Rerata persentase daya berkecambah tertinggi cenderung pada perlakuan W3K3 yaitu sebesar 95,33\%. Hasil ini sesuai dengan bobot 100 butir pada perlakuan W3K3 yang menghasilkan berat tertinggi yaitu 44,31 g. Semakin besarnya konsentrasi aplikasi PGPR diduga akan meningkatkan populasi mikroba PGPR pada bintil akar sehingga membantu tanaman untuk penyerapan dan penyediaan unsur hara dengan optimal yang berpengaruh terhadap hasil produksi tanaman kacang tanah. Iswati, (2012) menyatakan bahwa konsentrasi aplikasi PGPR yang semakin tinggi maka pengaruhnya terhadap tinggi tanaman dan panjang akar tanaman tomat yang berpengaruh terhadap hasil produksi tanaman tomat juga semakin besar.

\section{Kecepatan Tumbuh}

Pemberian PGPR dengan perlakuan saat pemberian dan konsentrasi, serta interaksinya berpengaruh tidak nyata terhadap kecepatan tumbuh benih. Diduga benih yang digunakan memiliki cadangan makan yang cukup untuk melakukan perkecambahan. Hal ini didukung tercukupinya unsur hara dalam tanah dapat membantu tanaman untuk melakuakan proses fisiologisnya seperti pembentukan biji dapat berjalan secara optimum sehingga dapat menghasilkan produksi biji yang bernas secara maksimal.

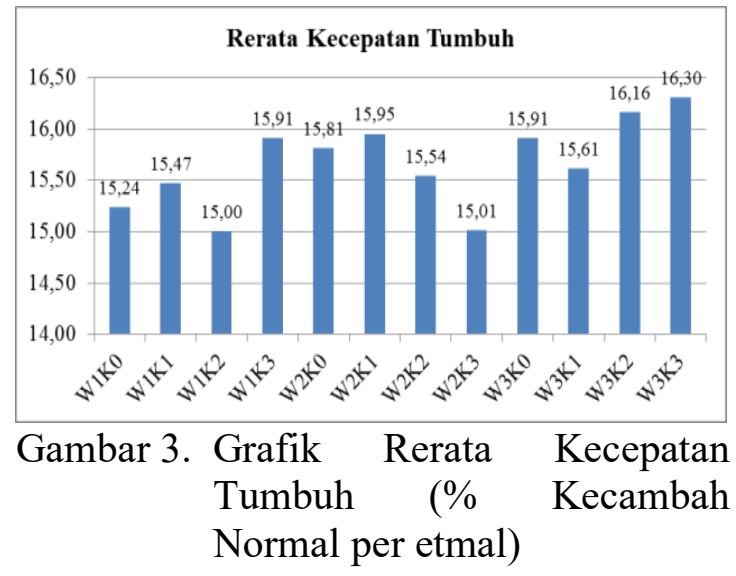

Gambar 3, menunjukkan rerata kecepatan tumbuh yang dihasilkan dari semua perlakuan kurang kuat. Benih yang mempunyai kecepatan tumbuh lebih besar dari $30 \%$ per etmal memiliki vigor kekuatan tumbuh yang kuat, jika kecepatan tumbuh antara $25-30 \%$ per etmal memiliki kekuatan tumbuh kurang kuat.

Kecepatan tumbuh benih kurang kuat diduga karena penyerapan air atau imbibisi yang dilakukan benih kacang tanah 
berjalan lambat. Hal ini karena cadangan makanan utama dari benih kacang tanah adalah lemak yaitu sebesar $42,5 \%$ untuk varietas Tuban. Melambatnya proses imbibisi dapat menyebabkan kecepatan tumbuh benih juga melambat karena air berperan penting dalam proses perkecambahan. Nurussintani et al., (2013) menyatakan bahwa faktor yang berpengaruh terhadap kecepatan perkecambahan dalam proses imbibisi ialah komposisi kimia benih.

\section{Keserempakan Tumbuh}

Pemberian PGPR dengan perlakuan saat pemberian dan konsentrasi PGPR, maupun interaksinya berpengaruh tidak nyata terhadap kecepatan tumbuh benih. Hal ini sesuai dengan parameter daya berkecambah dan kecepatan tumbuha benih dengan perlakuan PGPR berpengaruh tidak nyata terhadap ke dua parameter tersebut.

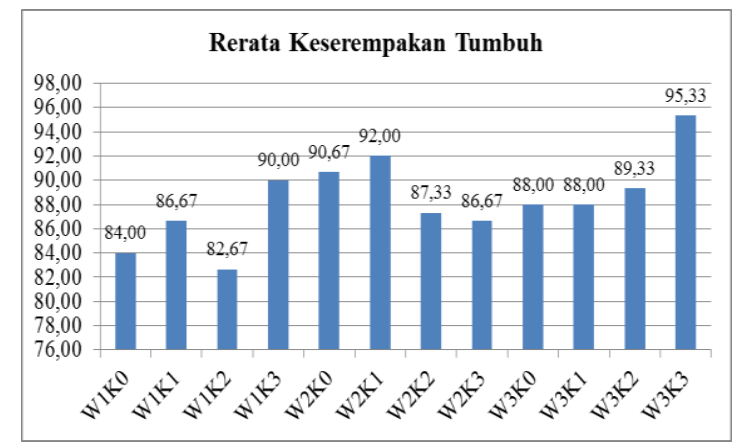

Gambar 4. Grafik Rerata Keserempakan Tumbuh $\quad(\% \quad$ Kecambah Normal Kuat)

Gambar 4, menunjukkan rerata keserempakan tumbuh yang dihasilkan dari semua perlakuan memiliki vigor benih yang tinggi. Keserempakan tumbuh $<40 \%$ memiliki vigor yang kurang kuat dan keserempakan tumbuh $>70 \%$ memiliki vigor yang tinggi.

Rerata keserempakan tumbuh tertinggi cenderung pada perlakuan W3K3 yaitu pemberian PGPR dengan konsentrasi $12,5 \mathrm{ml} / \mathrm{L}$ satu minggu setelah tanam sebanyak empat kali yaitu sebesar $95,33 \%$. Hasil ini sesuai dengan hasil parameter bobot 100 butir pada perlakuan W3K3 yang menghasilkan berat tertinggi yaitu 44,31 g. Keserempakan tumbuh benih diduga dipengaruhi oleh ukuran benih yang sesuai dengan pernyataan Sutopo (2002) yang menyatakan bahwa salah satu faktor yang mempengaruhi vigor benih adalah morfologis benih yaitu ukuran besar kecilnya ukuran benih akan berpengaruh terhadap kekuatan tumbuh benih.

Diduga semakin besarnya konsentrasi aplikasi PGPR akan meningkatkan populasi mikroba PGPR yang akan memaksimalkan pertumbuhan dan produksi tanaman kacang tanah karena PGPR membantu penyerapan unsur hara. (Iswati, 2012) menyatakan bahwa aplikasi PGPR dengan konsentrasi 12,5 ml/L dapat menghasilkan tinggi tanaman dan panjang akar tertinggi yang berpengarub terhadap hasil produksi pertumbuhan tanaman tomat

\section{KESIMPULAN}

Dari hasil dan pembahasan dapat disimpulkan bahwa saat pemberian PGPR dan interaksi antara saat pemberian dan konsentrasi PGPR berpengaruh tidak nyata terhadap semua parameter.

Konsentrasi PGPR berpengaruh nyata sampai sangat nyata terhadap parameter pertambahan tinggi tanaman fase vegetatif (15 HST sampai 30 HST), pertambahan tinggi tanaman stadium pembentukan polong (30 HST sampai 45 HST), umur berbunga rata-rata, berat basah polong per rumpun, berat kering polong per rumpun, bobot 100 butir benih, dan produksi polong kering per hektar. Konsentrasi terbaik adalah konsentrasi PGPR $12,5 \mathrm{ml} / 1$

\section{DAFTAR PUSTAKA}

A'yun, K. Q., Hadiastono, T., \& 尌 Martosudiro, M. (2013). Pengaruh Penggunaan PGPR (Plant Growth Promoting Rhizobacteria) terhadap 
Intensitas TMV (Tobacco Mosaic Virus), Pertumbuhan, dan Produksi pada Tanaman Cabai Rawit (Capsicum frutescens L.). Jurnal Hama Dan Penyakit Tumbuhan, l(1), 47.

Aiman, U., Sriwijaya, B., \& Ramadani, G. 虽 (2015). Pengaruh Saat Pemberian PGPRM (Plant Growth Promoting Rhizospheric Microorganism) terhadap Pertumbuhan dan Hasil Buncis Perancis. In Prosiding Seminar Nasional \& Internasional. Universitas Muhammadiyah Surakarta.

Anesta, D. O., Nyana, I. D. N., \& E Astiningsih, A. A. M. (2016). Studi Hasil dan Kualitas Benih Padi P05 dengan Pemberian Pupuk Hayati (Enterobacter cloacae). E-Jurnal Agroekoteknologi Tropika (Journal of Tropical Agroecotechnology), 5(2), 116-126.

Badan Pusat Statistik. (2015). Produksi 钢 Kacang Tanah Menurut Provinsi (ton), 1993-2015. Retrieved from https://www.bps.go.id/dynamictable /2015/09/09/874/produksi-kacangtanah-menurut-provinsi-ton-19932015.html

Elfianti, D. (2005). Peranan mikroba 钢 pelarut fosfat terhadap pertumbuhan tanaman. Jurusan Kehutanan Fakultas Pertanian. Universitas Sumatera Utara. Universitas Sumatra Utara.

Fauziah Aini Rohmawati, R. S. dan K. (2016). Pengaruh Pemberian PGPR (Plant Growth Promoting Rhizobacteria) dan Kompos Kotoran Kelinci terhadap Hasil Tanaman Terung (Solanum melongena L.). Jurnal Protan.
Febriyanti, L. E., Martosudiro, M., \& 信 Hadiastono, T. (2015). Pengaruh Plant Growth Promoting Rhizobacteria (PGPR) terhadap Infeksi Peanut Stripe Virus (PStV), Pertumbuhan dan Produksi Tanaman Kacang Tanah (Arachis hypogaea L.) Varietas Gajah. Jurnal Hama dan Penyakit Tumbuhan, 3(1), 84.

Husen, E., Saraswati, R., \& Hastuti, R. D. EQ (2006). Rizobakteri pemacu tumbuh tanaman. In R. D. . Simanungkalit, D. A. Suriadikarta, R. Saraswati, D. Setyorini, \& W. Hartatik (Eds.), Pupuk Organik dan Pupuk Hayati (pp. 191-210). Bogor: Balai Besar Litbang Sumberdaya Lahan Pertanian Badan Penelitian dan Pengembangan Pertanian.

Irfan, M. (2013). Respon Bawang Merah 㰯 (Allium ascalonicum L) Terhadap Zat Pengatur Tumbuh dan Unsur Hara. Agroteknologi, 3(2), 35-40. https://doi.org/10.24014/ja.v3i2.86

Iswati, R. (2012). Pengaruh dosis formula EQ pgpr asal perakaran bambu terhadap pertumbuhan tanaman tomat (Solanum Lycopersicum syn). Jurnal Agroteknotropika, 1(1).

Jumin, H. B. (2002). Agronomi. Jakarta: 钢 PT Raja Grafindo Persada.

Leingo, R. (2014). Aplikasi Zat Pengatur EQ Tumbuh terhadap Pertumbuhan dan Produksi Tanaman Tomat (Lycopersicon esculentum Mill) (Skripsi). Universitas Negri Gorontalo.

Lindung. (2014). Teknologi Pembuatan 㰯 dan Aplikasi Bakteri Pemacu Pertumbuhan Tanaman (PGPR) dan Zat Pengatur Tumbuh (ZPT). 
Nurussintani, W., Damanhuri, D., \&

琶 Purnamaningsih, S. L. (2013).

Perlakuan Pematahan Dormansi terhadap Daya Tumbuh Benih 3 Varietas Kacang Tanah (Arachis hypogaea). Jurnal Produksi Tanaman, 1(1).

Pitojo, S. (2005). Benih Kacang Tanah. 尌 Yogyakarta: Kanisius.

Pratama, H. W., Baskara, M., \& Guritno, B. (2014). Pengaruh Ukuran Biji dan Kedalaman Tanam Terhadap Pertumbuhan dan Hasil Tanaman Jagung Manis (Zea mays saccharata Sturt). Jurnal Produksi Tanaman, 2(7), 577-582.

Rukmana, R. (1998). Kacang tanah. 尌 Yogyakarta: Kanisius.

Suhartina. (2005). Deskripsi Varietas

Unggul Kacang-kacangan dan Umbi-umbian. Malang: Balai Penelitian Tanaman Kacangkacangan dan Umbi-umbian.

Sutopo, L. (2002). Teknologi Benih. EQ Jakarta: Raja Grafindo Persada. 